DOI: http://dx.doi.org/10.15260/rbc.v9i2.383

\title{
Criminalística
}

\author{
V. W. Botteon ${ }^{a^{*}}$ \\ ${ }^{a}$ Instituto Geral de Perícias de Santa Catarina (IGP/SC), Brasil. \\ *Endereço de e-mail para correspondência: victor botteon2@hotmail.com \\ Recebido em 15/05/2019; Revisado em 05/05/2020; Aceito em 05/05/2020
}

\section{RESENHA DESCRITIVA}

O livro intitulado "Criminalística" chega a sua $7^{\mathrm{a}}$ edição recentemente publicada (2019) pela Millenium Editora, integrando a coletânea do "Tratado de Perícias Criminalísticas", sendo uma obra idealizada pelo mestre Victor Paulo Stumvoll, com coordenação do professor Domingos Toccheto, e contando com a colaboração de diversos autores de renome, como Alberi Espindula, Cleber Muller, Marcos Passagli, Luiz Eduardo Dorea, dentre outros especialistas das mais diversas áreas das ciências forenses.

A obra é estruturada em 12 capítulos, objetivando abordar os principais conceitos e assuntos relacionados à disciplina da Criminalística, base de todo o trabalho pericial. Os temas são tratados com linguagem acessível ao público e de forma bastante objetiva. Além do conteúdo acadêmico de qualidade para a orientação e o desenvolvimento do trabalho de profissionais da área, a obra apresenta diversos pontos cobrados nos conteúdos programáticos de concursos para o ingresso em cargos da área de perícias criminalísticas, sendo considerada uma obra referência para os estudos do público concurseiro.

No capítulo $1^{\circ}$, o autor introduz a Criminalística ao leitor, contando sobre alguns fatos marcantes de sua história e apresentando os seus postulados e princípios fundamentais. No capítulo seguinte, a legislação inerente ao trabalho pericial é detalhada, uma vez que o Direito Processual Penal é indissociável do trabalho do perito criminal. O capítulo $3^{\circ}$ trata sobre o local de crime, discorrendo sobre a importância do isolamento e da preservação para a realização dos procedimentos de levantamento do local. No $4^{\circ}$ Capítulo, o leitor é apresentado às definições e classificações de vestígios e indícios, assim como a procedimentos de coleta, acondicionamento e armazenamento dos vestígios.

$\mathrm{Na}$ sequência, os principais vestígios biológicos de importância forense e as respectivas análises são apresentados, como sangue, pelos e fios de cabelo, saliva, sêmen e ossos. $\mathrm{O}$ capítulo $6^{\circ}$ trata sobre o levantamento de local e do exame perinecroscópico em casos de morte violenta. $\mathrm{O}$ capítulo $7^{\circ}$ aborda sobre os exames periciais relacionados a fragmentos de vidros presentes em locais de crime. No capítulo $8^{\circ}$, a identificação veicular é abordada, demonstrando as principais fraudes constatadas na numeração de chassi e em documentos de veículos. O capítulo $9^{\circ}$ aborda sobre os principais exames periciais relacionados a crimes ambientais e a valoração do dano ambiental. $\mathrm{O} 10^{\circ}$ capítulo discorre sobre análise forense de solo, desde a coleta de vestígios do solo até a apresentação de casos concretos . O capítulo 11 trata de perícias específicas da área da contabilidade, desde as descrições de livros contábeis aos exames periciais realizados nos principais crimes financeiros relacionados à área. Finalizando a obra, o último capítulo trata sobre aplicações de microscopia eletrônica de varredura (MEV) nos mais variados tipos de amostras de importância forense, encerrando uma obra obrigatória para quem trabalha ou deseja ingressar e trabalhar na área pericial.

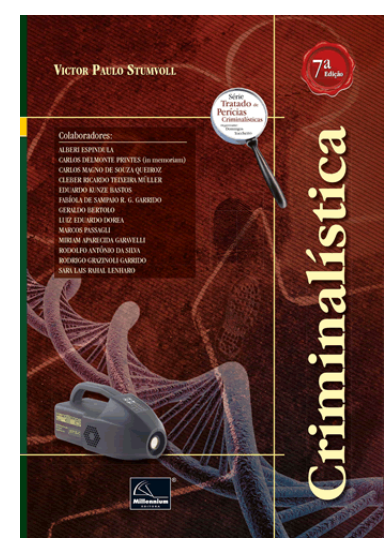

Criminalística / Victor Paulo Stumvoll. Campinas - SP: Millennium Editora, 2019.

Número de páginas: 440; Formato: $23 \mathrm{~cm}$ por $16 \mathrm{~cm}$. ISBN: 978-85-7625-368-6 